\title{
Culture Default and Principles of Translation Compensation in Literary Translation - a Case Study of Book III of Ashoka the Great
}

\author{
Cheng Zhen \\ School of Foreign Languages and Literatures, Lanzhou University, Lanzhou 730000, China \\ E-mail: jane_zhencheng@foxmail.com
}

\begin{abstract}
As a historical novel about the Peacock Dynasty in India, Ashoka the Great, to some extent, reflects the ancient Indian culture, so it is of great translation value for cultural exchange. When translating the third volume of Ashoka the Great, the author found a large number of expressions with Indian characteristics hindering readers' understanding of the TT. Both sides of the communication have the same background knowledge, so they can omit the elements which are self-evident to both sides. The omitted part can be called cultural default. Therefore, the strategies of translation compensation should be adopted to solve the problem of understanding caused by cultural default in order to promote communication between different cultures successfully. After summarizing the principles of translation compensation based on previous studies, the author analyzes the parts of culture default in this novel and uses five principles of translation compensation: literal translation with a footnote, paraphrasing, amplification, domestication and foreignization. The present author hopes this paper can provide effective reference for the translation of Ashoka the Great.
\end{abstract}

Keywords: Book III of Ashoka the Great, cultural default, principles of translation compensation

\section{Introduction}

With the advancement of globalization, cultural exchanges between countries are becoming more and more frequent. However, ordinary Chinese people know a little about Indian culture except for Tagore, Buddhism and several Indian films. In recent years, China and India have begun to communicate more frequently in political, economic and cultural aspects. Therefore, the translation of Book III of Ashoka the Great is beneficial to the cultural communication between the two countries.

Due to the cultural differences between China and India, there are many difficulties in the process of translating this novel from English to Chinese. The book involves a lot of Indian cultural knowledge, such as ancient Indian religions, philosophy, and cultural allusions, resulting in the phenomenon of cultural default.

Based on the characteristics of the novel, this paper summarizes the cultural default in ST. Consulting the literature and referring to the previous research results, the author puts forward corresponding strategies of translation compensation to guide the translation of this novels. These parts are self-evident to the SL readers, but incomprehensible to the TT readers. Five typical examples with corresponding strategies translation and analysis results of the advantages and disadvantages of each strategy are given in this article. Try to make the TT not lose the Indian cultural characteristics and the language style of the ST, but also accurately convey information of the ST to the TT readers, in line with the expression habits of the TL.

\section{Ashoka the Great and its writer}

J.E.Steur introduces that Ashoka the Great, a historical fiction, chronicles the life of Emperor Ashoka who lived in the Mauryan dynasty of India in 3rd Century BEC. In the fiction, there are distinctive characters, a complicated plot, a description of ancient Indian religious culture and art, vivid and beautiful language style. The original Dutch version was trilogy, published separately in 3 volumes. The original writer, Wytze Keuning, was a headmaster of a primary school in Netherlands. He started writing this book in 1937 when World War II on the verge. The war made him feel it necessary to write the book which inspired people to realize Ashoka's lifelong goal: to prevent war. When Wytze Keuning published the first two manuscripts, the Netherlands had been invaded, which required the consent of the occupier. At that time, many believed that seeking and obtaining the consent of the occupying power was an act of cooperation with the aggressors. Because of his determination and unremitting efforts, these two books were successfully published. Three years after World War II., the third book of the trilogy was published in 1948. However, European countries are busy with post-war reconstruction, so these books have not attracted people's attention. When Wytze Keuning died in 1957, the books were almost forgotten. ${ }^{[1]}$ 
J.E.Steur, a Dutchman who was interested in Indian Culture, translated the books from Dutch to English, combined the trilogy into one book, and then published it in 2010. J.E.Steur indicates in his book that the original version was written in a very outdated Dutch and in a style of courtesy, which makes it hardly readable for people of today. In his translation version, the language style is elegant and vivid which is in line with customs of language expression in modern society.

Although China borders on India, we know very little about Indian culture, compared to western culture. In that case, its Chinese translation is of remarkable significance for promoting the cultural exchange between China and India. In this article, the author will analysis the difficulties and solutions when translating J.E.Steur's version from English to Chinese.

\section{Culture default and principles of translation compensation}

As a basis for interpretation of course, some information will be assumed to be present or even need not to be mentioned, when both sides of communication are under the same culture background. That kind of information can be called default elements. Brown and Yule mentioned culture default in Discourse Analysis published in 1983. He said that"It is a feature of these knowledge representation that they are organized in a fixed way as a complete unit of stereotypic knowledge in memory.",[2]

"Translators with very limited competence in the source language are, however, at a great disadvantage and must often compensate for this lack by obtaining the help of someone who may be work in the target language but who is fully competent in the source language." ${ }^{[3]}$

Wang Dongfeng, a Chinese scholar who is president of the School of Foreign Languages in Sun Yat sen University, published an article about culture default in 1997 . According to his theory, in the process of communication, if both sides have common background knowledge or pragmatic premise, it will be more economical to achieve the purpose of communication, thus the self-evident information can be omitted. The part omitted by both sides of the communication as the shared knowledge background is called situational default. If the missing part is related to the intralingual information, it is contextual default, while that related to the cultural background outside the text is cultural default. From the perspective of reconstruction of discourse coherence, Wang Dongfeng puts forward several ways of translation compensation, such as literal translation with a footnote, compensation within the text, domestication, deletion, literal translation. ${ }^{[4]}$

Wang Dalai, a Chinese scholar, proposed three principles of translation compensation: literal translation with a footnote or an endnote, compensation within the text and adaption. In 2004 he suggested that when writing, the writer of the ST will assume that he or she share the same cultural background with readers and hide the obvious information in the background knowledge. For TT readers from different cultures, because of lack of proper knowledge of different cultural backgrounds, they cannot understand the omitted information, thus causing the cultural default. ${ }^{[5]}$

In Ashoka the Great, there is a lot of information about Brahmanism and Buddhist cultures, Indian mythology, Indian philosophy, Indian customs and ancient India political background, with which ordinary Chinese readers are not familiar. Consequently, that leads to cultural default. After summarization of the theories and their principles of translation compensation based on previous studies, five principles of translation compensation could be used on translating J.E.Steur's version of Ashoka the Great from English to Chinese, including literal translation with a footnote, paraphrasing, amplification, domestication, literal translation.

\section{Principles of translation compensation in the translation of Book III of Ashoka the Great}

Different countries have different cultural customs, histories, religions, political and social systems. Therefore, it is necessary to adopt strategies of translation compensation to solve the problems caused by cultural default. Only in this way can the TT readers thoroughly understand the cultural information in the ST. Ashoka the Great, as an Indian historical fiction, is characteristic of words and sentences of Indian religions and culture, which will be difficult to understand by Chinese readers without dealing with principles of translation compensation. After looking up literatures about theories of translation composition, it is found that five translation strategies can be adopted in rendering the novel, including literal translation with a footnote, paraphrasing, amplification, domestication and foreignization.

Literal translation with a footnote means that the part about cultural default is translated literally in the text, and then add comments to explain outside the context. Paraphrasing means that the part of cultural default is explained properly within the text, transmitting the ST information to the TT readers. Amplification means that the part about cultural default is translated literally. And for helping the TT readers understand the meaning, add few words such as category words to it in the text. Domestication means that replace the expression of the original culture with the expression conforming 
to the culture of TL. Foreignization means that the expression of the original culture is adopted without affecting the understanding of the target language readers, which make the TT absorbs the features of loanwords and requires the translator to be close to the author.

\subsection{Literal translation with a footnote}

When the elements in the SL involve complex knowledge cultural background, and their meaning cannot be rendered to readers of the TT in a few words or sentences, literal translation with a footnote should be adopted. Literal translation with a footnote means that the part about cultural default is translated literally in the text, then add comments to explain outside the context. It can introduce the culture of the ST to the TT readers in footnotes because of annotation not limited by space. The advantages of this translation method are that it can minimize the cultural loss and retain the characteristics of the source language culture to the maximum extent. However, this method also has some disadvantages, that is, readers of the TT have to interrupt the reading process and reduce reading speed by looking for explanations in the notes.

For example:

"I have taken the most beautiful there is of Brahmanism, Gracious Majesty, because all the sects originate from there. I knew of your sacred tolerance from the 12th rock-lipi.” ( Chapter 17 of Book III, P827 )

“我选了婆罗门教传说里最优美的故事，仁慈的陛下，因为所有的教派都起源于婆罗门教，我从《第十二摩 崖法敕》中了解您对宗教的宽容。”

(Note: Brahmanism evolved from Vedicism in the 6th century BC. Hinduism is the predecessor of Hinduism. It is characterized by the Vedic apocalypse and the omnipotence of sacrifices. The hierarchy is strict, and people are divided into four castes. The Indian caste system will People are divided into four levels, Brahman, Kshatriya, Veda, and Sudra. All levels have struck each other from generation to generation.

The rock-lipi refers to the edicts issued by King Ashoka to promote Buddhism. These edicts are carved on stones and distributed throughout the country. It is mainly divided into two categories. One is the rock-lipi, carved on the local rock wall. There are 14 chapters in total, and the content is to promote Buddhism. The other is stone pillars, besides there are some small edicts, carved in grottoes. "The 12th rock-lipi" is roughly as follows: respect all religions and set up lawrectification supervisors. )

Brahmanism is an ancient Indian religion characterized by Brahman supremacy and sacrifice supremacy. Deriving form it, the caste system divides people into four classes: Brahman, Kshatriya, Veda and Sudra, and each level is inherited from generation to generation. Rock-lipis are the decrees engraved on stones by Asoka and distributed all over the country in order to spread Buddhism. The content of the 12th rock-lipi is to respect all religions and set up supervisors of dharma. For those who are familiar with Indian religious background, the meanings of Brahmanism and the 12th rock-lipi are unspoken. However, ordinary Chinese readers do not understand the meaning of these two words, which leads to cultural default. This requires strategy of translation compensation to help the TT readers understand its meaning. These two terms contain rich information on Indian religious culture and social background, thus literal translation with a footnote is suitable for transiting such text.

\subsection{Paraphrasing}

Paraphrasing means that the part of cultural default is explained properly within the text, transmitting information of the ST to the TT readers. If the cultural factor of the SL involving specific cultural background knowledge is widely used and has lost its referential meaning, it is difficult to render them literally into another language. In this case, the image and form in source text should be changed to achieve the purpose of being faithful to the meaning of source text. The advantages of this translation strategy are that it will not interrupt the readers' reading process and give the translator more freedom.

For example:

"These years were filled with such an overwhelming amount of work that I only could think in flashes of awareness of the two of us, my Devi. Pataliputra called me! Soon, I felt glad that you and the children had not accompanied me into that cavern of death and yet I missed you the most, you who always gave me strength." (Chapter 19 of Book III, P850)

“缇毗, 这些年海量的政务填满了我的生活, 只能想一下我们俩在一起的感觉。华氏城需要我! 很快我便庆 幸你和孩子没有跟我一起去那死亡之地, 那时我最想念的就是你，你总是给我力量。”

In ST, "that cave of death" refers to a city, where political struggles can kill people at any time. If it is translated into Chinese “死亡洞穴”, the TT readers will not understand what the "cave" is. As a result, the TT readers will have confusion and doubt about this word. Therefore, paraphrasing should be adopted to deal with this part. "That cavern of death" in the ST does not refer to a real cavern, but to a dangerous place, so it should be rendered as "the land of death", 
that is, “死亡之地”.

\subsection{Amplification}

Amplification means that the part about cultural default is translated literally, and for helping the TT readers understand the meaning, add few words such as category words to it in the text. The advantages of this translation strategy are that it retains the cultural image of the ST and at the same time breaks down the cultural barriers for the TT readers without interrupting the reading process. However, this method also has some limitations, which will destroy the aesthetic perception of the ST and can only deliver limited information to the TT readers.

For example:

All those begging monks at the houses in their ashen robes, with their shaven heads and the ever-present begging bowl clutched in their arms like a child! To be obedient and sweetly behaving! And all that to reserve a place in heaven or even to reach Nirvana! In the older world was more vigour, belief, life! (Chapter18 of book III, P837)

那些在屋子里乞讨的和尚, 都穿灰袍, 剃光头, 像小孩一样, 手里一直紧紧抱着乞讨的碗! 遵循戒律、积德 行善! 一切都是为了进人极乐世界, 甚至达到涅盘的永恒境界! 还是以前的世界更有活力, 那才是信仰和生活!

Nirvana is a term in Indian Buddhism, which means the state of eternal happiness beyond the trouble of life and death. Buddhists practice and faith involves finding inner peace and calm. Therefore, Nirvana, the highest state of Buddhist practice, will never have all kinds of troubles, pains, torment and samsara in life. Buddhists are familiar with Nirvana, but ordinary readers don't understand the meaning of this word. Transliterate the word as “涅槃” and then add a brief explanation “永恒境界”, which means eternal state. In this way, without looking for notes or dictionaries, TT readers can understand the meaning of this religious term and experience the exotic flavor of the ST.

\subsection{Domestication}

When there are culture defaults like idiom and allusions in the original culture in the ST, and the literal translation cannot be accepted by the TT readers, domestication should be adopted. Domestication means that replace the expression of the original culture with the expression conforming to the culture of TL. Domestication makes the target text reader oriented and conforms to the cultural expression of the target language. The advantage of this method is that it is in line with the cultural expression habits of the target language. It can make TT readers understand the part of culture default more vividly, and make ST readers associate with the same general meaning with TT readers. However, the disadvantage of this method is that it will damage the artistic creation of the original author and lose the characteristics of the source language culture.

For example:

"And then, when you are safe with your necklace in Pataliputra, I may look for you like the Brahmins do for the elixir of life ... Upon my death! Find someone else for this dangerous job. The holy Maharajah protects the tree, ask him!" she laughs mockingly. ( Chapter 18 of Book III, P842)

“不, 之后你会带着这串项链安然无恙地回到华氏城, 我要找你难如登天……直找到死! 你另找人冒这个 险吧，国王把这棵树保护起来了，不如你去问问他！”她嘲笑道。

In Indian culture, "the Brahmins do for the elixir of life refers to Brahman" refers to the highest caste in India making a kind of medicine in pursuit of immortality. The core meaning of this proverb is that something is extremely difficult, even impossible. As a Chinese idiom “难如登天” means as difficult as to climb up to the sky, which is a metaphor for something extremely difficult to do. The two proverbs almost have the same meaning. After dealing with the translation in this way, TT readers will have similar feeling to the TT readers.

\subsection{Foreignization}

In 1995 Venuti advocated that in his The Translator's Invisibility Venuti advocates "the use of foreignization strategy to preserve the exotic flavor and reflect the cultural differences, and opposes the invisibility of the translator." ${ }^{,[6]}$ Foreignization means that the expression of the original culture is adopted without affecting the understanding of the target language readers, which make the TT absorbs the features of loanwords and requires the translator to be close to the author. The advantage of this translation method is that it can reflect the exotic flavor of the SL culture to the maximum extent. But due to no uniform translation standard in this way, sometimes translation problems will puzzle the TT readers.

For example:

If Alexander had not come from Macedonia to this country of barbarians, they would still make their temples and palaces from wood! The pillars look like the spindly shanks of a hungry sailor of Odysseus, the mausoleums are circular heaps of stone within a small fence! (Chapter 20 of Book III, P862) 
如果不是亚历山大大帝从马其顿来到这个野蛮的国家, 他们还在用木头建造庙宇和宫殿呢! 这些柱子看起来 像俄狄浦斯手下饥饿水手的小细腿，他们的陵墓就是围在小栅栏里圆形石头堆！

In the ST, "spindly shanks of a hungry sailor" is the expression used by the Greek artist to ridicule the ugliness of pillars made by Indian craftsmen. Greece is a coastal country, and this expression is very consistent with their culture and customs. Moreover, even for TT readers who live in inland areas, images of hungry people's bodies and trunks can make them associate with ugliness and vulgarity.

Translation is a special inter-lingual and cross-cultural communicative act. In order to make readers feel the SL culture more deeply and intuitively, the method can be adopted on the basis of not hindering the fluency of reading and the comprehension of readers.

\section{Conclusion}

The author translated J.E.Steur's version of the third volume of Ashoka the Great from English to Chinese. By analyzing and summarizing the culture loaded words in ST, the author selects five ways of translation compensation: literal translation with a footnote, paraphrasing, amplification, domestication and foreignization, which can effectively compensate for the lack of cultural information in the TT and effectively spread culture. However, the author has found her own shortcomings in the process of translation. For examples, the language style is not very beautiful, some aspects are not well understood and the expression is not concise enough. Therefore, the author needs to constantly improve translation skills and accumulate knowledge and experience. In conclusion, the author adopts five principles of translation compensation to deal with the parts of cultural default, hoping this article will offer references for the study of the text and promote cultural exchanges between China and India.

\section{References}

[1] Wytze Keuning. Ashoka the Great. Translated by J. E. Steur. New Delhi: Rupa Publications India Pvt. Ltd.; 2010.

[2] Brown G, Yule G. Discourse Analysis. London: Cambridge University Press; 1983.

[3] Nida E. A. Language and Culture Contexts in Translating. Shanghai: Shanghai Foreign Language Education Press; 2001.

[4] Wang Dongfeng. Cultural Default and Reconstruction of Textual Coherence. Journal of Foreign Languages.1997; (6):56-61.

[5] Wang Dalai. One of Principles of Compensation for Cultural Default in Literary Translation. Journal of Wenzhou University. 2004; (4):30-35.

[6] Venuti, Lawrence. The Translator's Invisibility: a History of Translation. London: Routlege; 1995. 